\title{
PERBANDINGAN METODE PEMBELAJARAN DEMONSTRASI DENGAN METODE TUTOR SEBAYA TERHADAP HASIL BELAJAR SISWA SMK
}

\author{
Huda H. Mutholib ${ }^{1}$, Wowo S. Kuswana ${ }^{2}$, Tatang Permana ${ }^{3}$ \\ Departemen Pendidikan Teknik Mesin \\ Universitas Pendidikan Indonesia \\ Jl. Dr. Setiabudhi No. 207 Bandung 40154 \\ dha.42hms@gmail.com
}

\begin{abstract}
ABSTRAK
Tujuan penelitian ini adalah untuk mengetahui perbandingan metode pembelajaran demonstrasi dengan metode tutor sebaya terhadap hasil belajar siswa. Penelitian ini menggunakan metode quasi experiment dengan desain nonequivalent control group design. Populasi dalam penelitian ini adalah siswa kelas XI SMKN Bantarkalong paket pilihan teknik kendaraan ringan yang berjumlah 4 kelas dengan jumlah siswa sebanyak 140 orang. Sampel penelitian dibagi menjadi dua kelas yaitu kelas eksperimen yang menggunakan bahan ajar metode demonstrasi dan kelas kontrol yang menggunakan bahan ajar metode tutor sebaya. Instrumen yang digunakan pada penelitian ini berupa soal pre test dan post test, kedua soal tes tersebut digunakan untuk melihat peningkatan hasil belajar siswa. Hasil pengolahan, analisis pengujian data diperoleh rata-rata hasil belajar siswa setelah menggunakan bahan ajar metode demonstrasi sebesar 81,73 dan rata-rata hasil belajar siswa setelah menggunakan bahan ajar metode tutor sebaya sebesar 77,3. Hasil perhitungan $\mathrm{N}$-Gain pada kelas eksperimen yang menggunakan bahan ajar metode demonstrasi sebesar 0,5, sedangkan hasil perhitungan $N$-Gain pada kelas kontrol yang menggunakan bahan ajar metode tutor sebaya sebesar 0,35. Perbedaan penggunaan bahan ajar metode demonstrasi dengan bahan ajar metode tutor sebaya terhadap hasil belajar siswa sebesar 0,23. Penelitian ini dapat disimpulkan bahwa: rata-rata hasil belajar siswa setelah menggunakan bahan ajar metode demonstrasi berada pada kategori sedang; rata-rata hasil belajar siswa setelah menggunakan bahan ajar metode tutor sebaya berada pada kategori sedang; peningkatan hasil belajar pada kelas eksperimen (pembelajaran menggunakan metode demonstrasi), lebih baik dibandingkan dengan peningkatan hasil belajar kelas kontrol (pembelajaran dengan metode tutor sebaya).
\end{abstract}

Kata kunci: demonstrasi, tutor sebaya, hasil belajar, starter.

\section{PENDAHULUAN}

Tujuan pendidikan nasional dengan jelas termasuk dalam pembukaan UUD 1945, yakni mencerdaskan kehidupan bangsa. Tujuan sistem pendidikan nasional adalah mencerdaskan kehidupan bangsa dan mengembangkan manusia Indonesia seutuhnya, yaitu manusia beriman dan bertakwa terhadap Tuhan Yang Maha Esa dan berbudi pekerti luhur, memiliki pengetahuan dan keterampilan, kesehatan jasmani dan rohani, berkepribadian dan mandiri serta tanggung jawab kemasyarakatan dan kebangsaan. Pendidikan nasional bertujuan untuk membentuk karakter seseorang yang beriman dan bertakwa yang tidak saja sebagai intelektual namun keberhasilan dalam pendidikan karakter dan budi pekerti anak.

\footnotetext{
${ }^{1}$ Mahasiswa Departemen Pendidikan Teknik Mesin FPTK UPI

2 Dosen Departemen Pendidikan Teknik Mesin FPTK UPI

${ }^{3}$ Dosen Departemen Pendidikan Teknik Mesin FPTK UPI
} 
Sebagai ilustrasi, materi ajar di SMK yang berkompetensi keahlian Teknik Kendaraan Ringan (TKR), pada standar kompetensi perbaikan, khususnya sistem starter dan komponenkomponennya dengan sub kompetensi perbaikan sistem starter yang harus diajarkan guru. Sebab itu, materi ajar tentang sistem starter membahas tentang prinsip kerja sistem starter, komponen-komponen sistem starter, fungsi dari masing-masing komponen, langkah kerja perbaikan atau servis komponen pada sistem starter yang sesuai dengan standar operasional prosedur (SOP), peraturan dan prosedur/kebijakan yang berlaku.

Hasil observasi lapangan (kelas) sebagai penelitian pendahuluan, bulan Februari 2015, pada proses kegiatan belajar mengajar (KBM) menunjukkan aktivitas peserta didik dalam proses belajar-mengajar rendah dan bersifat pasif yaitu cenderung hanya sebagai penerima saja. Peserta didik kelihatan tidak bersemangat banyak yang mengantuk dan kurang memperhatikan materi yang disampaikan guru. Peserta didik kurang berminat selama mengikuti proses pembelajaran, peserta didik kurang berani mengemukakan pendapatnya bila diberi pertanyaan oleh guru. Proses KBM didominasi dengan kegiatan mencatat di papan tulis dan ceramah sehingga hasil belajar yang diperoleh siswa tidak optimal. Metode pembelajaran adalah cara untuk mempermudah peserta didik mencapai kompetensi tersebut (Ahmadi, 2011). Hal ini lah yang membuat penulis beranggapan bahwa ada ketidak sesuaian mengenai penggunaan metode pembelajaran yang digunakan oleh guru dalam menyampaikan materi sehingga berakibat tidak tuntasnya pembelajaran seluruh siswa. Metode yang dipergunakan oleh guru belum sesuai dengan keadaan siswa pada saat ini.

Metode pembelajaran demonstrasi ini merupakan salah satu metode pembelajaran yang memiliki kadar praktikum. Metode pembelajaran demonstrasi bertujuan untuk mempermudah penyampaian materi yang bersifat prosedur pekerjaan yang menyenangkan, menarik, mudah dimengerti karena dalam pembelajarannya siswa bisa melihat langsung dengan benda kerja asli ketika proses pembelajaran berlangsung (Azis, 2007).

Selain dari metode pembelajaran metode demonstrasi di atas, metode pembelajaran lainnya adalah metode Tutor Sebaya yang merupakan metode pembeljaran yang dilakukan dengan cara memperdayakan kemampuan siswa yang memiliki daya serap yang tinggi dengan tujuan untuk memberikan bimbingan belajar bagi siswa yang mengalami kesulitan belajar (Winkel, 2004). Metode tutor sebaya ternyata memberikan hasil yang signifikan dan memiliki pengaruh positif terhadap hasil belajar. Metode pembelajaran tutor teman sebaya mempunyai kontribusi sebesar 26,7\% dalam meningkatkan hasil belajar berdasar regulasi-diri pada mahasiswa. Pembelajaran aktif bisa dilakukan tanpa harus melibatkan banyak tenaga 
pengajar. Selain itu, proses pembelajaran bisa dimaksimalkan dengan potensi yang ada, diantaranya melalui tutor teman sebaya. Sehingga perlu melakukan penelitian terhadap metode pembelajaran demonstrasi dan metode tutor sebaya pada standar kompetensi sistem starter terhadap hasil belajar siswa.

\section{METODE PENELITIAN}

Metode yang digunakan dalam penelitian ini adalah metode kuasi eksperimen (Quasi Exsperimental Design). Selama melakukan eksperimen, siswa merupakan objek penelitian yang tetap mengikuti pelajaran dalam kelas seperti biasa. Selain itu, pemilihan objek penelitian juga tidak dilakukan secara acak. Desain penelitian yang digunakan dalam penelitian ini adalah non equivalent control group design yaitu menempatkan subjek penelitian ke dalam dua kelompok kelas yang terdiri dari kelompok eksperimen dan kelompok kontrol yang tidak dipilih secara acak.

\section{HASIL PENELITIAN}

Penelitian dilakukan terhadap siswa kelas XI SMK Bantarkalong Paket Pilihan Teknik Kendaraan Ringan, dengan sampel kelas XI TKR 1 sebagai kelas eksperimen yang menggunakan metode demonstrasi dengan jumlah siswa sebanyak 30 orang. Data yang diperoleh pada penelitian ini berupa data pretest, data posttest. Data-data tersebut akan digunakan untuk mendeskripsikan data secara kuantitatif, sehingga akan diperoleh kesimpulan hasil penelitian untuk pengujian hipotesis. Data hasil belajar siswa kelas eksperimen (metode demontrasi) diperoleh rata-rata pretest 62,8 dan rata-rata posttest 81,7.

Hasil belajar siswa dapat diketahui dengan melakukan beberapa tahapan yaitu pre test, treatment dan post test. Hasil belajar siswa dapat diperoleh setelah melakukan proses pembelajaran yang diukur melalui tes. Tes ini dilakukan dua kali yang pertama pretest (tes sebelum melakukan pembelajaran) dan posttest (tes setelah melakukan proses pembelajaran). Kemampuan awal siswa sebelum melakukan proses pembelajaran (Dimyati dan Mudjiono, 2009). Diagram tersebut menunjukkan bahwa rata-rata kemampuan awal siswa sebelum menerima materi pembelajaran menggunakan metode demonstrasi sebesar 62,80 atau masih berada di bawah KKM (75). Diagram di atas juga menunjukkan nilai rata-rata hasil belajar siswa setelah menerima materi pembelajaran menggunakan metode demonstrasi (posttest). 
Nilai rata-rata siswa setelah menerima materi pembelajaran menggunakan metode demonstrasi sebesar 81,7. Nilai rata-rata tersebut berada pada kategori sedang.

Data hasil belajar siswa kelas kontrol (metode tutor sebaya) diperoleh rata-rata pretest 64,8 dan rata-rata posttest 77,3 . Hasil belajar siswa dapat diketahui dengan melakukan beberapa tahapan yaitu pretest,treatment dan posttest. Hasil belajar siswa dapat diperoleh setelah melakukan proses pembelajaran yang diukur melalui tes. Tes ini dilakukan dua kali yang pertama pretest (tes sebelum melakukan pembelajaran) dan posttest (tes setelah melakukan proses pembelajaran). Kemampuan awal siswa sebelum melakukan proses pembelajaran menunjukkan bahwa rata-rata kemampuan awal siswa sebelum menerima materi pembelajaran menggunakan metode tutor sebaya sebesar 64,8 atau masih berada di bawah KKM (75). Nilai rata-rata hasil belajar siswa setelah menerima materi pembelajaran menggunakan metode metode tutor sebaya (posttest). Nilai rata-rata siswa setelah menerima materi pembelajaran menggunakan metode metode tutor sebaya sebesar 77,3. Nilai rata-rata tersebut berada pada kategori sedang.

\section{PEMBAHASAN}

Perbedaan hasil belajar siswa menggunakan metode demonstrasi dengan metode tutor sebaya berada pada kategori sedang. Hasil belajar siswa menggunakan metode tutor sebaya lebih rendah apabila dibandingkan dengan hasil belajar siswa menggunakan metode demonstrasi (Wowo, 2014). Pembelajaran menggunakan metode tutor sebaya hanya menghasilkan skor rata-rata pretest sebesar 64,8 , skor rata-rata post test sebesar 77,3, dan skor rata-rata $N$-Gainnya adalah sebesar 0,35 . Sedangkan hasilpembelajaran menggunakan metode demonstrasihanya menghasilkan skor rata-rata pretest sebesar 62,8 , skor rata-rata posttest sebesar 81,7, dan skor rata-rata $N$-Gainnya adalah sebesar 0,50.

Perbedaan kemampuan hasil belajar awal dan akhir siswa sebelum melakukan dan sesudah melakukan proses pembelajaran menunjukkan bahwa rata-rata kemampuan awal dan akhir siswa sebelum menerima dan sesudah menerimamateri pembelajaran menggunakan metode tutor sebaya dan metode demonstrasi (Arikunto, 2009). Perbedaan hasil belajar siswa dilihat dari skor rata-rata $\mathrm{N}$-Gain nyapada kelas kontrol atau kelas yang menggunakan metode tutor sebayaadalah sebesar 0,35. Sedangkan hasil belajar siswa pada kelas eksperimen atau kelas yang menggunakan metode demonstrasi menghasilkan skor rata-rata $\mathrm{N}$-Gain nya adalah sebesar 0,50 . 


\section{KESIMPULAN}

Penelitian ini dapat disimpulan sebagai berikut: hasil belajar siswa pada kelas eksperimen yang mengikuti pembelajaran menggunakan metode demonstrasi lebih baik. Skor rata-rata hasil belajar pada kelas eksperimen adalah hasil belajar pretest-nya berada pada kategori kurang, sedangkan hasil belajar posttest-nya meningkat berada pada kategori sedang. Hasil belajar siswa pada kelas kontrol yang mengikuti pembelajaran menggunakan metode tutor sebaya lebih rendah pada hasil posttest-nya di bandingkan dengan hasil post test dengan siswa yang mengikuti pembelajaran menggunakan metode demonstrasi. Skor rata-rata hasil belajar pada kelas kontrol adalah hasil belajar pretest-nya berada pada kategori kurang, sedangkan hasil belajar posttest-nya meningkat berada pada kategori sedang. Peningkatan hasil belajar pada kelas eksperimen (pembelajaran menggunakan metode demonstrasi), lebih baik dibandingkan dengan peningkatan hasil belajar kelas kontrol (pembelajaran dengan metode tutor sebaya).

\section{DAFTAR PUSTAKA}

Ahmadi. (2011). Strategi Pembelajaran Berorientasi KTSP. Jakarta: Prestasi Pustakaraya. Arikunto, S. (2009). Dasar-dasar Evaluasi Pendidikan. Jakarta: Bumi Aksara.

Azis, A. (2007). Metode dan Model-Model Mengajar. Bandung: Alfabeta.

Dimyati dan Mudjiono. (2009), Belajar dan Pembelajaran. Jakarta: PT. Rineka Cipta.

Winkel, W.S. (2004). Psikologi Pengajaran. Yogyakarta: Media Abadi.

Wowo, S.K. (2014). Biopsikologi Pembelajaran Perilaku. Bandung: Alfabeta. 